University of Nebraska - Lincoln

DigitalCommons@University of Nebraska - Lincoln

\title{
Application of a Geomorphic and Temporal Perspective to Wetland Management in North America
}

Loren M. Smith

Oklahoma State University - Main Campus, loren.smith@okstate.edu

Ned H. Euliss Jr.

U.S. Geological Survey, ceuliss@usgs.gov

Douglas A. Wilcox

SUNY-Brockport, dwilcox@brockport.edu

Mark M. Brinson

East Carolina University

Follow this and additional works at: https://digitalcommons.unl.edu/usgsnpwrc

Smith, Loren M.; Euliss, Ned H. Jr.; Wilcox, Douglas A.; and Brinson, Mark M., "Application of a Geomorphic and Temporal Perspective to Wetland Management in North America" (2008). USGS Northern Prairie Wildlife Research Center. 271.

https://digitalcommons.unl.edu/usgsnpwrc/271

This Article is brought to you for free and open access by the US Geological Survey at DigitalCommons@University of Nebraska - Lincoln. It has been accepted for inclusion in USGS Northern Prairie Wildlife Research Center by an authorized administrator of DigitalCommons@University of Nebraska - Lincoln. 


\title{
APPLICATION OF A GEOMORPHIC AND TEMPORAL PERSPECTIVE TO WETLAND MANAGEMENT IN NORTH AMERICA
}

\author{
Loren M. Smith ${ }^{1}$, Ned H. Euliss, Jr. ${ }^{2}$, Douglas A. Wilcox ${ }^{3,5}$, and Mark M. Brinson ${ }^{4}$ \\ ${ }^{1}$ Department of Zoology \\ Oklahoma State University \\ Stillwater, Oklahoma, USA 74078 \\ E-mail: loren.smith@okstate.edu \\ ${ }^{2}$ U.S. Geological Survey \\ Northern Prairie Wildlife Research Center \\ $8711-37^{\text {th }}$ Street $S E$ \\ Jamestown, North Dakota, USA 58401 \\ ${ }^{3}$ U.S. Geological Survey \\ Great Lakes Science Center \\ 1451 Green Road \\ Ann Arbor, Michigan, USA 48105 \\ ${ }^{4}$ Biology Department \\ Howell Science Complex, N-108 \\ East Carolina University \\ Greenville, North Carolina, USA 27858 \\ ${ }^{5}$ Present Address: \\ Department of Environmental Science and Biology \\ 350 New Campus Drive \\ SUNY-Brockport \\ Brockport, New York, USA 14420
}

\begin{abstract}
The failure of managed wetlands to provide a broad suite of ecosystem services (e.g., carbon storage, wildlife habitat, ground-water recharge, storm-water retention) valuable to society is primarily the result of a lack of consideration of ecosystem processes that maintain productive wetland ecosystems or physical and social forces that restrict a manager's ability to apply actions that allow those processes to occur. Therefore, we outline a course of action that considers restoration of ecosystem processes in those systems where off-site land use or physical alterations restrict local management. Upon considering a wetland system, or examining a particular management regime, there are several factors that will allow successful restoration of wetland services. An initial step is examination of the political/social factors that have structured the current ecological condition and whether those realities can be addressed. Most successful restorations of wetland ecosystem services involve cooperation among multiple agencies, acquisition of funds from non-traditional sources, seeking of scientific advice on ecosystem processes, and cultivation of good working relationships among biologists, managers, and maintenance staff. Beyond that, in on-site wetland situations, management should examine the existing hydrogeomorphic situation and processes (e.g., climatic variation, tides, riverine flood-pulse events) responsible for maintenance of ecosystem services within a given temporal framework appropriate for that wetland's hydrologic pattern. We discuss these processes for five major wetland types (depressional, lacustrine, estuarine, riverine, and man-made impoundments) and then provide two case histories in which this approach was applied: Seney National Wildlife Refuge with a restored fen system and Bosque del Apache National Wildlife Refuge where riverine processes have been simulated to restore native habitat. With adequate partnerships and administrative and political support, managers faced with degraded and/or disconnected wetland processes will be able to restore ecosystem services for society in our highly altered landscape by considering wetlands in their given hydrogeomorphic setting and temporal stage.
\end{abstract}

Key Words: case histories, ecosystem restoration, hydrogeomorphic setting 


\section{INTRODUCTION}

As outlined by Euliss et al. (2008), the failure of managed wetlands to provide a broad suite of ecosystem services (e.g., carbon storage, wildlife habitat, ground-water recharge, contaminant filtering, floodwater storage) of value to society has been caused by a lack of consideration of the processes that maintain productive wetland ecosystems or by physical and social forces that restrict a manager's ability to apply actions that allow those processes to occur. This is often the result of wildlife managers trying to maintain static conditions in wetlands for specific wildlife populations without considering the temporal cycles that wetlands need to undergo to achieve productivity for specific groups of wildlife, such as dabbling ducks (e.g., Smith 1990, Euliss et al. 2004). Possibly more often, a manager's ability to influence ecosystem processes effectively is restricted by physical factors in surrounding watersheds (e.g., Junk et al. 1989, Merbach et al. 2002, Gleason et al. 2003). These could be dams, for example, which do not allow management of flood-pulse processes essential to productivity of riparian systems or landuse changes in up-gradient areas that confound sitespecific wetland management (e.g., Brinson and Verhoeven 1999, Junk and Wantzen 2006). They could also be simple water withdrawals from streams and rivers by agricultural interests or municipalities that constrain potential management of riverine or estuarine systems (e.g., Friedman et al. 1998, Wolanski 2007). In most cases, sediments and nutrients associated with land use in upper watersheds complicate management of wetlands for all ecological goods and services, including wildlife (e.g., Luo et al. 1997, U.S. Environmental Protection Agency 2000). Finally, economic or policy forces far-removed from a wetland often interact to prevent occurrence of basic ecosystem processes (http://www.nrcs.usda. gov/technical/NRI/ceap/wetlands, Euliss et al. 2008).

In this paper, we propose alternatives to the traditional, and often static, view of wetland management by outlining a course of action that considers restoration or simulation of ecosystem processes in those systems where off-site land use or physical alterations restrict local actions. Moreover, in today's environment, we note that a wetland manager must enter fiscal and policy realms to be successful. Scientists and managers must be able to communicate effectively the value of successful wetland management to provide ecosystem services for society. This communication often extends beyond agency administrators to local and national politicians and society. We note that forming partnerships among agencies, seeking wetland science advice, and forming a good working relationship among biological, maintenance, and administrative personnel are key to successful restoration.

\section{A TEMPORAL AND GEOMORPHIC VIEW}

We propose that upon considering management of wetland ecosystems, there are several factors that a manager should initially consider to restore a productive wetland system that provides a broad suite of services to society. One of the first steps is to examine the policy/social factors that have structured the current wetland condition and whether those realities can be addressed. Discussion among agencies usually provides excellent perspective. Beyond on-site wetland management scenarios, managers should first determine the existing hydrogeomorphic situation and processes responsible for maintenance of ecosystem services. Again, failure to do so results in unproductive wetlands providing few services to society (Euliss et al. 2008). Seeking counsel from wetland scientists and managers with experience in specific systems is often fruitful. Below, we discuss five major wetland types (depressional, riverine, lacustrine, estuarine, and man-made impoundments) and the processes that drive their ecology. We then examine temporal aspects of each system. For example, are temporal cycles being statically manipulated or is a perceived low in wildlife productivity simply a temporal and necessary drying phase in a wetland? Later, we provide two examples for the application of this management vision and examples of the consequences of not following this view. All of these considerations vary by region and associated wetland types.

\section{Depressional Wetlands}

As the term "depression" implies, these wetlands occur within depressions in the landscape, each essentially set within its own catchment or watershed (Brinson 1993). That is, as low points in elevation, runoff in the catchment or watershed moves to the depression. They also receive direct precipitation but may or may not receive shallow subsurface flow and/or ground water. Thus, depressional wetlands can be recharge or discharge wetlands, or a combination of both, as influenced by space and time (Euliss et al. 2004). Conserving or managing depressional wetlands, therefore, without considering the surrounding watershed, will often compromise the processes that provide essential ecosystem services (e.g., Luo et al. 1997, Merbach et al. 2002). 
Examples of depressional wetlands include prairie potholes in the glaciated Northern Great Plains, playas in the Southern Great Plains, pocosins and Carolina bays in the Southeastern U.S., and vernal pools in California (Cowardin et al. 1979). In higher latitudes, many of these wetlands were formed through glacial action, while in southern U.S. regions, depressions such as playas were formed by dissolution of the underlying substrate and wind (Smith 2003, Mitsch and Gosselink 2007). Still others could have been formed through historic fluvial events.

Depressional wetlands provide a wide range of ecosystem services to human society. As noted by Euliss et al. (2008), much of the original conservation of depressions occurred because of their fish and wildlife (biotic) habitat value. In addition, they can be important storage sites of carbon, a significant climate change service (Euliss et al. 2006), as well as important ground-water recharge sites (Zartman et al. 1996). They also store floodwaters (National Research Council 1995), reducing flooding of households, farmlands, forests, and prairies. Finally, they serve as important sites of aesthetic pleasure, field education classrooms, and scientific investigations (Smith 2003).

Because depressional wetlands are the endpoints of runoff within a landscape, they receive and accumulate chemicals, pesticides, and sediments from activities in the surrounding watershed. Sediments can completely change the hydrology (e.g., Luo et al. 1997), altering the resultant wetland hydroperiod and changing the entire structure and function of the system. They can also, more subtly, bury egg and seed banks (Gleason et al. 2003). Most sediment enters depressional wetlands as a result of erosion from cultivation of the surrounding watershed (Luo et al. 1999). In addition, because many depressional wetland types recharge underlying aquifers, pesticides and other chemicals that accumulate in their sediments can potentially contaminate ground water used by municipalities or for irrigation (Zartman et al. 1996). Finally, because most depressional wetlands are considered "isolated," they are no longer considered jurisdictional "Waters of the United States" and do not receive federal protection from dredge and fill activities regulated under the Clean Water Act (Haukos and Smith 2003). This has resulted in the continued loss of many depressional wetlands as a result of urban, agricultural, and transportation expansion throughout their range.

Many depressional wetlands targeted for conservation by government agencies were simply purchased and set aside (Euliss et al. 2008). It was assumed that these wetlands would provide their wildlife service with little or no active management. Examples include Waterfowl Production Areas in the northern Plains and playas on U. S. Forest Service National Grasslands (Smith 2003). Where the watershed was protected in these instances, it allowed wetlands to progress through natural climatic variation, maintaining the processes necessary for ecological function and provision of ecosystem services.

However, in many instances, either the watershed was not protected or hydrologic modifications were made to the basin. When the watershed was not protected, this resulted in sedimentation altering the hydrology, which then influenced all biotic processes (e.g., Luo et al. 1997, Smith and Haukos 2002, Euliss et al. 2004). Thus, passive management of depressional wetlands without adjacent watershed protection was often unsuccessful. Moreover, many depressional wetlands had level ditches or pits dug in them to provide surface water for longer periods of time (e.g., Euliss and Mushet 2004). Again, this altered hydrology restricted the full suite of ecosystem services. Littoral zone primary production, for example, declined, and exotic species often become established. Most often, this alteration was assumed to benefit waterfowl populations, but frequently it was also used to provide a more secure source of water for domestic livestock (Smith 2003, Euliss and Mushet 2004). Finally, islands were often constructed in the center of depressional wetlands, ostensibly to provide predator-secure nesting sites for waterfowl (e.g., Dahl et al. 2003, Shaffer et al. 2006). By dredging island material from the wetland basin, hydrology was also altered, which, in turn, altered other wetland services.

\section{Riverine Floodplains and Riparian Areas}

Riverine floodplains and streamside riparian areas (henceforth called riverine wetlands) occur everywhere there is sufficient surface-water flow to form concentrated flow paths. Floodplains and riparian areas are not differentiated here because they are located in similar geomorphic settings in river valleys (National Research Council 2002, Kroes and Brinson 2004). Further, riverine wetlands as treated here encompass the channel and floodplain as one functional unit (Brinson 1993).

Streams and floodplains together develop "fluvial geomorphologies" in which channel geometry (depth, width, meander length, etc.) follows predictable mathematical relationships in many cases (Leopold et al. 1964, Rosgen 1995). Dynamic channel meandering results in geomorphic complex- 
ity that contributes to biodiversity of riparian wetlands (examples cited in Brinson and Verhoeven 1999). An important characteristic of riverine wetlands is duration and frequency of overbank flow, commonly with a return period of about one to two years, although there are many exceptions (Knighton 1998, Sweet and Geratz 2003). The ecological significance of overbank flow is the "flood pulse" that contributes to species exchange between floodplains and permanent water bodies, between floodplains and terrestrial habitats, and between different floodplains (Junk and Wantzen 2006). Flood pulsing provides hydrologic energy to transport sediments, nutrients, propagules, and aquatic organisms. The generally high nutrient richness of floodplain forests supports rates of biomass production and standing stocks similar to those of upland forests (Megonigal et al. 1997). The channel portion of riverine wetlands is a corridor for anadromous and catadromous fish migration, as well as a pathway for delivery of continental sediments to floodplain surfaces (during overbank flow) and coasts for deposition in estuaries and delta-building (Gagliano et al. 1981, Day et al. 2000)

No other wetland type offers as many goods and services directly to human society. Historically, the channels of riverine wetlands were primary sources of transportation, the floodplains were locations for many settlements, and both portions supported subsistence fishing and hunting. Even today, large river corridors contribute to transportation and the dilution of point and non-point discharges of wastes from urban and agricultural land uses. Hunting and fishing that once supported subsistence-harvesting activities are now largely recreational endeavors: mere shadows of their original productivity, similar to the situation in estuaries (Lotze et al. 2006).

Alterations of riverine wetlands fall along a gradient of intensity from those that are relatively renewable (timber harvesting, hunting and fishing, dilution of wastewater) to those that are considered to be irreversible (flooding by dams, dredging for navigation, construction of flood-control levees, filling for highways and buildings) (Brinson 1990). Stream channelization for drainage and channel incision associated with urbanization largely eliminate overbank flow, a situation that shrinks or entirely eliminates riparian wetlands (Paul and Meyer 2001, Groffman et al. 2003). Legacies of channel alteration remain in many landscapes. In the case of millponds and subsequent infilling, the effects began centuries ago (Walter and Merritts 2008). Riverine wetlands in headwater regions have been extensively modified by small impoundments or levees to extend the hydroperiod for the purpose of enhancing waterfowl habitat (Lokemoen 1973, King and Allen 1996). One type, green tree reservoirs, has been shown to alter species composition, reduce tree growth, and increase tree mortality (King and Allen 1996). For impoundments of larger streams, wholesale changes take place through elimination of the flood pulse both upstream and downstream from dams. Upstream, the reservoir inundates an otherwise dynamic flooding regime. Downstream, the flood pulse is reduced by lowered frequencies of overbank flow due to dam release schedules and channel enlargement through incision and widening. This reduction in frequency or magnitude of high flows causes floodplains to dry and vegetation to transform toward plant species less tolerant of flooding (Johnson et al. 1976, Auble et al. 1994). Regardless, the critical function of flood pulsing in either case is reduced or removed whether upstream or downstream from a dam. Without overbank flow and flood pulsing, riverine wetlands lose an array of interdependent functions. The tradeoff between flood pulsing and more static hydrodynamics created by impoundments should be evaluated when waterfowl enhancement projects are proposed for riverine wetlands.

\section{Estuarine Fringe}

Tidal salt marshes are well-studied examples of the estuarine fringe wetland type commonly cited in textbooks. Zonation in the Atlantic coast marshes of North America is illustrated typically with the following sequence: 1) a tidal creek and natural levee, 2) zones of Spartina alterniflora Loisel. of varying heights in the regularly flooded region, 3) Juncus roemerianus Scheele, or J. gerardii Loisel. and $S$. patens (Aiton) Muhl. in the irregularly flooded high marsh, and 4) a mixture of less salttolerant graminoid, herbaceous, and shrub species in a zone adjacent to the upland, usually occupied by forest. While this pattern is common, estuarine fringe in North America also includes freshwater tidal marshes and forests along medium-to-large rivers, non-tidal swamp forests and brackish marshes in Albemarle and Pamlico Sounds of North Carolina, mangrove swamps in southern Florida, microtidal marshes along the Gulf Coast, marshes with barren salt flats at the upland margin in southern California, intertidal mud flats grading to sedge wetlands in the Pacific Northwest, as well as other variants. These ecosystems are among the most valued of the continent, in large part because of their contribution to habitat that supports estuarine fisheries. 
Common explanations for estuarine fisheries production are 1) the outwelling of organic matter from marshes to the subtidal region where detrital food webs ultimately support fish (Hopkinson 1985, Odum 1988) and 2) the marsh habitat itself as a nursery and refuge offering a concentrated source of organic matter and intense biogeochemical cycling (Kneib and Wagner 1994). Both have merit and are supported by the combined importance of auxiliary energy provided by tidal currents and the connection to a species-rich marine environment. Further, freshwater tidal marshes host fish assemblages that derive from both fresh and brackish regions (Odum 1980). In other cases, estuaries serve as a conduit to spawning areas of riparian wetlands. Estuarine fringe wetlands are recognized also for their capacity to absorb moderate storm surges. As human populations and their habitations increase in these regions, this service becomes especially important as illustrated by the Indonesian Tsunami in 2004 and the U.S. Gulf Coast-Hurricane Katrina in 2005.

Human activities interact with the dynamism of estuarine fringes in two ways. The first is to impound them for mosquito control, waterfowlhabitat enhancement, agriculture, and salt production. The ecological effects of these alternate land uses are predictable because they interfere with exchanges of water between the subtidal estuary and intertidal wetlands. The other interference is related to the lateral migration of wetlands landward in response to rising sea level (Brinson et al. 1995). Migration is impeded by bulkheads, roads, dwellings, and other types of barriers. Where migration is halted, and wetland shorelines continue to erode, the surface area of estuarine wetlands diminishes.

What happens to wetlands that are impounded or prevented from migrating landward? First, they are isolated from tidal currents and, thus, sources of sediments that are critical for vertical accretion in the face of rising sea level. Unless they are able to respond to rising sea level through the accumulation of organic matter while impounded, they will be converted to non-tidal wetlands that will lose elevation relative to increasing sea-level. Impounded high marshes originally used for hay production (Warren et al. 2002) have lost elevation both from subsidence within the impounded area, usually from peat oxidation, and from an intervening period of rising sea level. When these areas are restored, they are instead converted to low marsh areas with tidal creeks, rather than the high marsh vegetation that originally occupied the site (Christian et al. 2000). The upper Sacramento-San Joaquin Delta and San Francisco Bay salt ponds, California (USA), are colossal examples of the difficulty for restoration of the former coastal wetland, now as much as several meters below sea level (Brown and Pasternack 2004). Even discounting losses from impoundments, estuarine fringe wetlands are not keeping pace with rising sea level in places such as the Mississippi Delta (Day et al. 2000) and some areas of Chesapeake Bay (Kearney and Stevenson 1991). However, when sediment supplies are abundant, formerly diked wetlands, such as those in San Francisco Bay, can be restored to intertidal status once they are reconnected with the estuary (Williams and Orr 2002).

\section{Lacustrine Fringe}

Coastal freshwater wetlands occur along the shorelines of the Laurentian Great Lakes from Lake Superior eastward to Lake Ontario and on other large inland lakes worldwide. They can be classified based on morphological setting, which reflects the influence of lake processes, especially exposure to waves. These classifications have been generalized into three categories, with multiple layers of subcategories: lacustrine, riverine, and barrier-enclosed (Albert et al. 2005). Great Lakes wetlands differ from inland depressional wetlands in that they are shaped by large lake processes, especially long- and short-term fluctuations in water levels. Because marsh vegetation can tolerate water-level changes and often requires these changes to maintain diversity, marshes are the most common type of coastal wetland in the Great Lakes.

Fluctuating water-level is the major driving force affecting Great Lakes wetlands (Keddy and Reznicek 1986, Wilcox 1995, Environment Canada 2002, Wilcox and Nichols 2008). At frequencies that vary by lake, high-water-level years periodically eliminate competitively dominant emergent plants. In ensuing years when levels recede, less competitive species are generally able to grow from seed or other propagules, complete at least one life cycle, and replenish the seed bank before being replaced through competitive interactions. The cycle then repeats itself. Water-level changes are thus vital in maintaining wetland diversity, and alteration of natural hydrology can impact wetlands.

Management of coastal wetlands, including some areas of the Great Lakes, includes the use of dikes to control water levels. In the Great Lakes, diked wetlands are most prevalent along the U.S. shore of western Lake Erie. Most are managed with an emphasis on producing habitat and food resources for migrating ducks. The wetlands present today are likely very dissimilar to those that occurred historically. Prior to logging in the 1860 s, the shoreline 
was adjacent to the Great Black Swamp, a 48-kmwide wetland complex that extended southwest to New Haven, Indiana (Kaatz 1955). The primary land use in the watershed is now agriculture, which likely results in increased loading of silt and nutrients to waters destined for the lake. Much of the shoreline has also been developed for residential, industrial, and commercial uses. Breakwalls, revetments, groins, breakwaters, and segmented breakwaters (see Silvester and Hsu 1991) have been constructed in attempts to reduce coastal erosion. However, their net effect has been transport of sediments offshore (Silvester and Hsu 1991, Wilcox and Whillans 1999) and a reduction in the littoral transport of sand necessary to maintain barrier beaches that once protected wetlands from wave attack (Kowalski and Wilcox 1999). Wetlands along the shore were also diked, in part to gain water-level control and also to reduce wave attack associated with loss of the barrier beaches. However, the lakeside dikes impact coastal processes in the same manner as revetments.

Diked wetlands lack continuous hydrologic connection to the lake and thus do not perform similarly to natural coastal wetlands. Due to lack of interaction with lake waters, nutrient transport and processing function differently in diked wetlands (Robb and Mitsch 1989). Human-induced changes in water levels in diked wetlands generally do not coincide with natural patterns, as occasional drawdowns in the summer to elicit a response from the seed bank typically occur in the months when lake levels are highest. Although plant communities are more stable in diked wetlands (Gottgens et al. 1998), they lack the diversity of species and habitats found in coastal wetlands with natural cycles of high and low water levels (D. Wilcox, unpublished data). Fish communities are restricted to those species that gain access when water is pumped into the wetlands and thus have reduced diversity (Johnson et al. 1997, Markham et al. 1997). Critical spawning and nursery habitat for many lake species is also lost. Native unionid clams that rely on certain fish species to distribute glochidia may suffer also (Nichols and Wilcox 2002).

With the advent of greater attention to an ecosystem approach for managing refuge lands, some managers are beginning to recognize the limitations of diked wetlands in the coastal zone. Major actions, such as constructing new dikes, are now also limited by the requirement for environmental impact statements dictated by the National Environmental Policy Act. As a result, when the proposal was made to restore Metzger Marsh (a former barrier beach wetland no longer protected by a barrier beach) on lands managed by both Ottawa National Wildlife Refuge and the Ohio Division of Wildlife, the initial design for diking the wetland was modified (Wilcox and Whillans 1999). Lack of sufficient sediment supply in the littoral drift of the lake would not allow a restored barrier beach to be maintained. Therefore, a dike was constructed to mimic the protective feature of a barrier beach, but a water-control structure was included in the dike to mimic the natural hydrologic connection found in the former natural barrier (Wilcox and Whillans 1999). The water-control structure also included a fish-passage system to exclude common carp ( $C y$ prinus carpio $\mathrm{L}$.) but allow other species to move into and out of the wetland (French et al. 1999, Wilcox and Whillans 1999). Restoration of wetland vegetation was largely successful (Kowalski and Wilcox 1999), diversity of the fish community has increased, northern pike (Esox lucius L.) now spawn there, and largemouth bass (Micropterus salmoides Lacepede) present a popular fishing opportunity (Johnson et al. 2004). Native clam populations are also thriving (Nichols and Wilcox 1997, 2004). Control of invasive plant species, especially common reed (Phragmites australis (Cav.) ex Steudel) presents continuing challenges (M. Carlson, U.S. Geological Survey, unpublished). The overall success of the Metzger Marsh restoration project resulted in a willingness among some managers to consider opening diked wetlands to the lake (Davis et al. 2006).

Impounded Wetlands

Unlike the previously described wetland types, impounded wetlands are constructed habitats that have had their natural processes completely altered. Humans have created impoundments for a myriad of purposes, ranging from harnessing energy to providing water for municipal and agricultural uses. Moreover, large wetland losses have occurred from impoundment creation, in addition to drainage, filling, and channelization (Dahl 1990, Dugan 1993). Impoundments have also been created on natural wetlands to provide more consistent wetland habitat, such as impoundments for waterfowl. However, creating static conditions with impoundments removes natural flooding and drying phases that keep these wetlands productive. Further, the increased hydraulic head at impoundment outlets contribute to downstream incision during spates. Thus, an understanding of the ecosystem processes that operated before and after impoundment creation is requisite to predicting how impoundments will function over time and respond to management 
prescriptions. Obviously, an impoundment within a tidal system, or even an inland coastal wetland, will function very differently from wetlands created by impounding rivers or streams, and because impounded wetlands are created habitats, they will function very differently from natural wetland types.

While humans tend to view impoundments, including naturally occurring impoundments, as long-term investments that provide a targeted service to society (e.g., flood-protection, waterfowl habitat), they clearly have finite life spans (Linsley et al. 1992). Beaver dams, for example, provide valuable wildlife habitat over considerable periods of time, albeit at different locations over time as existing dams breach and new ones are constructed. In fact, the ephemeral nature of beaver dams is the major factor influencing their value as wildlife habitat. Periodic flooding of previously dry areas provides the dynamic hydrology required to drive the system between productive states in much the same manner as has been described for flood-pulse processes of rivers (Davis et al. 2006), depressional wetlands (see Euliss et al. 2004), and freshwater coastal wetlands (Wilcox 1995, Environment Canada 2002). Human impounded wetlands have reduced temporal productivity because hydroperiods have been lengthened and water levels are relatively stable. Productivity in many impoundments, including those with water-control capability, is often reduced because water often cannot be completely drained as needed to simulate the dry phase; impoundments also elevate water-table mounds that make it even more difficult to oxidize deep sediments in the dry phase.

Impounded wetlands have short effective lives because they serve as settling basins within high energy systems that carry sediments and other allochthonous materials. Ultimately, all reservoirs will fill with sediment (Linsley et al. 1992). Further, filling rates are much greater in small reservoirs and impoundments that store less than 12 ha-m of water (Dendy 1968). Impounded wetlands also accumulate solutes such as salts, nutrients, and environmental contaminants, sometimes in quantities sufficient to compromise ecological services provided by the wetland (Presser and Barnes 1985, Euliss et al. 1989, Euliss and Mushet 2004). Although wetlands are often touted as nutrient sinks that improve water quality (see National Research Council 1995), excessive nutrient inputs contribute to negative impacts on wetland function. Phosphorus is an especially common nutrient in agricultural runoff that promotes wetland eutrophication and affects a shift from diverse native plant communities to invasive plants such as cattails (Typha spp.) (see review in Mitsch and Gosselink 2007: 625). Nutrient enrichment of wetlands also promotes release of greenhouse gases (Merbach et al. 2002), and wetlands with surface outflow (e.g., impounded wetlands) can become phosphorus-saturated and export excessive quantities of phosphate that degrade downstream aquatic habitats (Richardson 1985).

Biological costs of impounded wetlands also affect adjacent ecosystem services. Impoundments restrict movement and natural exchange between wetlands and their natural connections with other aquatic ecosystems, often resulting in negative influences on native biota and important processes. In coastal wetlands, impoundments restrict movement of fish and other organisms whose biology depends upon wetlands for a portion of their life cycle. Coastal marshes are also sources of nutrients and energy that are naturally exchanged with their connected marine and lake ecosystems. Impoundments in lotic systems are well known to constrain the movement of aquatic organisms, yet this problem has been poorly studied except for species of economic importance or species of conservation concern. Because impounded wetlands change hydroperiods, a concomitant shift in the biotic community also occurs (Euliss and Mushet 2004). Wetlands excavated or impounded to extend hydroperiods to benefit waterfowl and livestock negatively impacted native aquatic macroinvertebrate, amphibian, and plant communities (Euliss and Mushet 2004).

Despite their shortcomings, impounded wetlands represent a substantial portion of the wetland habitats available today and will continue to provide ecological services to society. However, their effective management requires knowledge of the functional processes that drive their ecology. In many cases, not all the available knowledge has been synthesized for wetland managers. To minimize sediment and nutrient accumulations, for example, managers will need area-specific information on composition of waters entering impounded wetlands to facilitate strategies to reduce import of materials that compromise management goals. In other cases, knowledge of the source of the unwanted imports can help identify upland areas to target with conservation programs that reduce erosion and conserve topsoil and agrichemicals. However, impounded wetlands will eventually fill with sediment, thus requiring remediation.

In certain landscapes where economics or policies make it unrealistic to restore natural wetlands, impounded wetlands may be the only option for 
wildlife managers to achieve wetland wildlife population or habitat goals. One example is California's Central Valley, where more than 95 percent of the original wetland area has been lost (Gilmer et al. 1982) and increasing demands for water and land resources make it unrealistic to recover significant portions of the original wetland area. Impounded wetlands in such areas are generally formed with dikes and use complex plumbing systems to deliver water. High quality water is preferred but may not always be available for management due to competition with domestic and agricultural interests. Because wetlands impounded in such locations are disconnected from natural drainages and low pressure systems are used to deliver water, these wetlands may be less susceptible to sediment accretion. Further, impounded wetlands in such areas are generally flooded only when needed as habitat for migratory birds, and their management frequently involves manipulation with heavy equipment to remove materials that accumulate in their basins. In California's Central Valley, wildlife managers have made good progress relating management activities to wildlife outcomes (Mensik and Paveglio 2004), including negative impacts from using poor quality water to flood impounded wetlands (Ohlendorf et al. 1986a,b, Euliss et al. 1989).

\section{CASE HISTORIES}

There are many cases where wetland managers recognized the need to correct past hydrologic alterations of the landscape and had the necessary upper-level administrative support and resources to achieve restoration successfully. These cases typically result from development of good working relationships among scientists, administrators, and managers that foster dialogue regarding management problems and proposed solutions. Managers identify problems and describe their desired solutions; scientists examine ramifications of those actions, collect and analyze data as needed, and make recommendations to improve upon the proposed solutions. Administrators provide the financial and personnel support necessary for implementation. Below are two examples, one with specific site details on a wetland in Seney National Wildlife Refuge, Michigan, and another on a broadscale view of a complex of wetland types at Bosque del Apache National Wildlife Refuge, New Mexico. These are simply examples. Many more are available and ongoing, such as the massive project in the Everglades National Park.

\section{Seney National Wildlife Refuge}

Seney National Wildlife Refuge is in the eastcentral Upper Peninsula of Michigan (Figure 1). The refuge contains a 20,000-ha sedge fen that receives springtime sheet flow, as well as groundwater discharge (Wilcox et al. 2006). The largest wetland drainage project in Michigan's history was initiated in 1912 when ditches (Walsh Ditch and tributary ditches) more than $30 \mathrm{~km}$ in length were dug across the peatland in an attempt to convert the land for agricultural use. The agriculture venture failed, the drainage system was abandoned, and the land was included in the refuge in 1935. Next, in the early 1940 s, numerous earthen dikes were constructed by the refuge perpendicular to the natural springtime sheet flow of water across the wetland to create potential open water wildlife habitat (Kowalski and Wilcox 2003). These two major alterations greatly changed the natural wetland hydrology and reduced the overall set of ecosystem services provided by the fen. In the late 1990s, refuge management faced with these conditions sought wetland science and administrative assistance in carrying out restoration.

Specifically, the conditions faced by management included a 6.3-km-long dike across the fen from southwest to northeast that created a 269-ha pool (C-3) in the 5,520-ha watershed (Figure 1). During winter, snow and ice accumulate in the watershed, to be released as surface flow in spring. Surface water accumulates behind the C-3 Pool dike and must be released. A control structure in the C-3 Pool dike regulates the level of $\mathrm{C}-3$ Pool and discharge to lower Walsh Ditch (Figure 1). Past management caused most excess water to be discharged to lower Walsh Ditch, resulting in erosion of peat and underlying sand and formation of a gully $50 \mathrm{~m}$ wide and $6 \mathrm{~m}$ deep. This erosion sent large volumes of sand to the downstream Manistique River, increasing its bed load and adversely affecting fish habitat. The water table in the adjacent peatland also declined, the peat surface subsided, and a lightning-strike peat fire that persisted for three months occurred in 1976 (Anderson 1982). C-3 Pool created habitat for some wildlife species, but the impoundment interrupted springtime sheet flow and converted peatland to open water.

U.S. Fish and Wildlife Service management at Seney NWR proposed to restore the large fen and reduce deposition of sand into the Manistique River by blocking Walsh Ditch. As a consequence of previous collaborations on other projects, the refuge management worked with wetland scientists, and many potential ramifications of the proposed action 


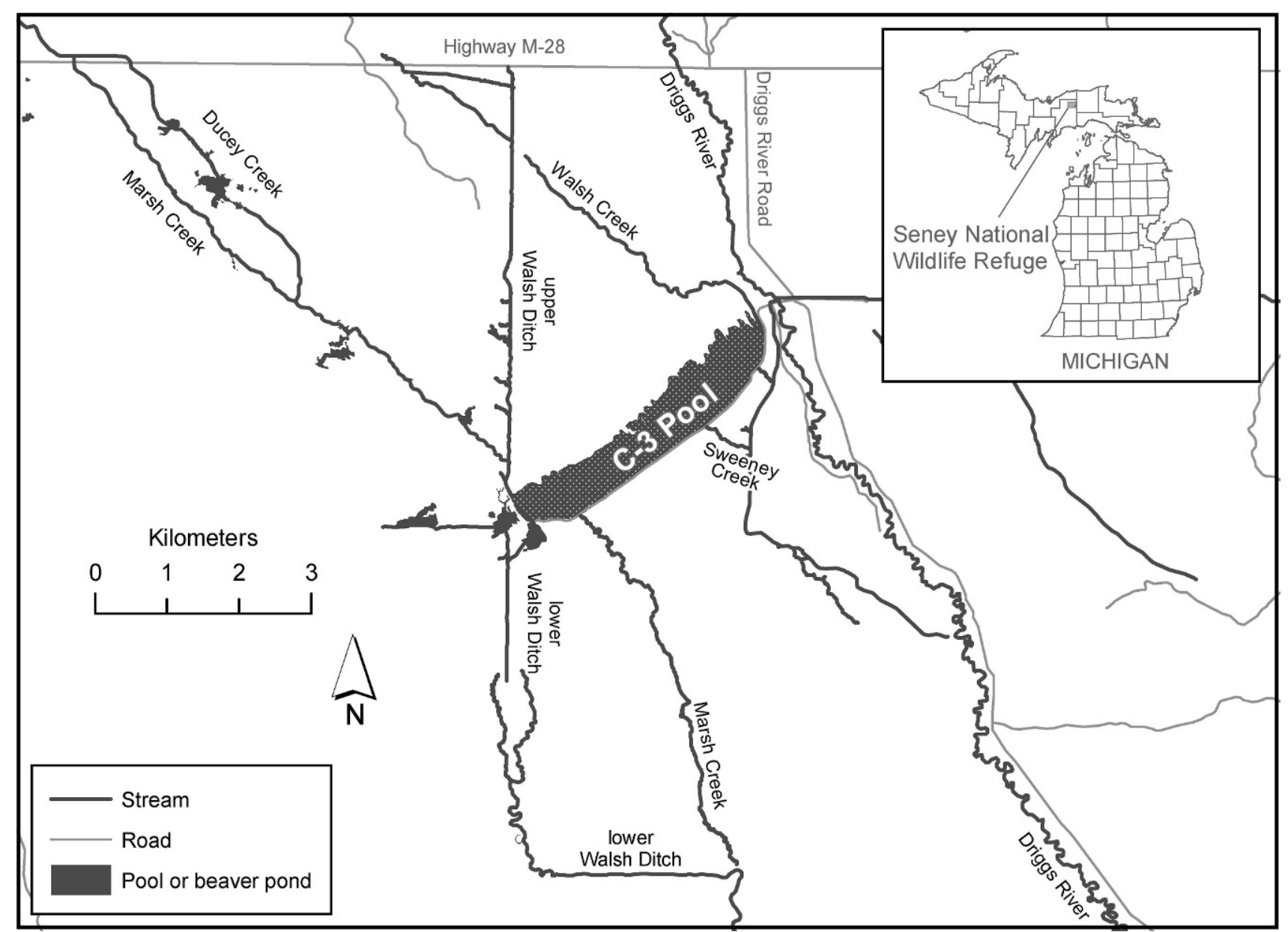

Figure 1. Map of the C-3 Pool and Walsh Ditch study site in Seney National Wildlife Refuge, MI showing water features. The entire drainage system flows generally from northwest to southeast, and Lower Walsh Ditch enters the Manistique River $20 \mathrm{~km}$ to the south.

were identified. Improper distribution of diverted water could cause erosion elsewhere and damage other wetlands or downstream property; improper treatment of the abandoned ditch could result in failure to restore natural ground-water flows; wetland vegetation would likely change in some areas as a result of new hydrologic alterations; and water chemistry in wetlands could change as a result of changes in water supply. The presence of beaver throughout the refuge could also affect hydrology and vegetation.

Refuge management requested that studies be conducted in association with restoration to provide guidance and pre-restoration data for use in evaluating environmental changes that occur during and following restoration. Management and scientists jointly arranged for funding and brought in coinvestigators with expertise as needed. Studies evaluated current ecological conditions related to presence of the ditch and pool (Kowalski and Wilcox 2003) and assessed hydrologic conditions in the wetland (Wilcox et al. 2006). As an outcome of those consultations, water flow in the portion of Walsh Ditch upslope from C-3 Pool was halted by construction of earthen dams across the ditch. These dams reduced localized removal of surface water and restored water levels in the ditch to those of the surrounding water table. During spring runoff, water overflowed creek channels and restored sheet flow of surface water across the area upslope from C-3 Pool. Standing water remained in the wetland even in summer when there is generally little flow in the creek, and ground-water discharge was readily observed at some locations (M. Tansy, U.S. Fish and Wildlife Service, retired, pers. comm.). Thus, closure of the ditch allowed ground-water discharge to restore the water table. A new water-control structure was also installed in the C-3 Pool dike that is capable of handling more water without undue erosion. Resulting flows to Marsh Creek also leave the channel, spread across the wetland, and restore sheet flow of surface water below C-3 Pool in the 
spring, per restoration goals (M. Tansy, pers. comm.). Springtime discharge that exceeds the capacity of downstream creeks, as determined by the hydrology study, can also be diverted to the Driggs River via another new structure, restoring natural springtime flows and addressing an unforeseen restoration goal.

Moreover, beaver dams are being established on lower Walsh Ditch, seemingly supported by groundwater discharges. Beaver occasionally constructed dams in the ditch in past years, but extreme flows in spring washed them out. In portions of lower Walsh Ditch, where deep gullying has not occurred, beaver dams may raise the water level in the ditch sufficiently to eliminate unnatural excessive ground-water discharge and lowering of the water table that was observed in the adjacent wetland, thus helping meet the ground-water restoration objective. However, if beavers do not persist, plans are available to install earthen dams across the ditch channel every $400 \mathrm{~m}$ to raise the level of surface water and adjacent water table, which would also allow sheet flows to pass over the ditch system (M. Tansy, pers. comm.). Such an approach, using metal sheet piling, proved successful in Big Meadows, a ditched sedge fen in Rocky Mountain National Park in Colorado (Cooper et al. 1998) with characteristics similar to those at Seney. However, it is unlikely that dams of any type can be constructed that will raise the water level completely in the heavily eroded gully area. It is also unlikely that dried peat will rehydrate and regain its full hydraulic properties (Okruszko 1995).

\section{Bosque del Apache National Wildlife Refuge}

Similar to most rivers in the U. S., the Rio Grande has been greatly altered in the past 150 years. It has been dammed and levied throughout much of its length, while it also has water withdrawn for agricultural and municipal purposes (Taylor et al. 1999). Bosque del Apache National Wildlife Refuge is situated in the Middle Rio Grande Valley $40 \mathrm{~km}$ south of Socorro, New Mexico (Figure 2). The geomorphic setting is a floodplain situated among mountain ranges to the west and east. The climate is arid and precipitation fluctuates $(20 \mathrm{~cm}$ annual precipitation) greatly, as does snowmelt.

Prior to extensive upstream modifications and construction of on-site levees and canals, the river channel on the refuge was able to scour and deposit sediment and change channel location within a wide floodplain (5.2 km width). Geomorphology and hydrology were driven by spring snow melt in upstream and adjacent mountain ranges, and summer monsoons. However, snow pack and monsoonal moisture varied greatly on an annual basis, and therefore, conditions driving wetland processes varied on the same scale (Taylor et al. 1999). These processes permitted the formation of riparian woodland gallery forest dominated by cottonwood (Populus deltoides Batr. ex. Marsh) and willow (Salix spp.) with a diversity of other woody species. It also permitted formation of seasonal wetlands dominated by annual seed-producing plants and wet meadows dominated by perennial grasses (Taylor and Smith 2003). The result was a mosaic of different aged riparian woodlands, meadows, and seasonal wetlands.

Exotic salt cedar (Tamarix spp.) and Russian olive (Elaeagnus angustifolia L.) were introduced into the region in the 1940 s and by the 1980 s became two of the dominant woody species in the floodplain. Throughout the floodplain, only scattered older cottonwood/willow riparian sites remained. Meadows and seasonal wetlands had either become cultivated farmland (dependent on irrigation) or desert scrub due to a lowered water table and lack of overbank flooding. Farm fields were graded with laser-level technology, eliminating topographic variation, and were surrounded by a water delivery system that diverted water from the river throughout the managed floodplain.

Managing wetland habitats in this highly modified environment was challenging. In the 1980s, the Refuge biologist, maintenance staff, and managers began to address the situation from an ecosystem perspective. Moreover, the Bosque del Apache NWR team sought help from wetland scientists and applied their combined understanding of the Middle Rio Grande geomorphic and hydrologic setting, biotic communities, and climate to develop new approaches for restoring wetland habitat. In addition, the biological and management staff then sought support for these restoration efforts from traditional U.S. Fish and Wildlife Service management sources, as well as non-traditional sources such as non-governmental organizations and federal grant opportunities (e.g., North American Wetlands Conservation Act). The Refuge developed a strong citizen support group and a network of communication among governmental agencies. All of these factors are interrelated and key to the Refuge's success in restoring wetland services.

The refuge embarked on an aggressive wetland management program targeting creation and/or restoration of seasonal wetlands, meadows, and riparian woodlands. Initially, artificial plantings (pole planting) of native trees replaced salt cedar removed from the historic floodplain (Swenson and 

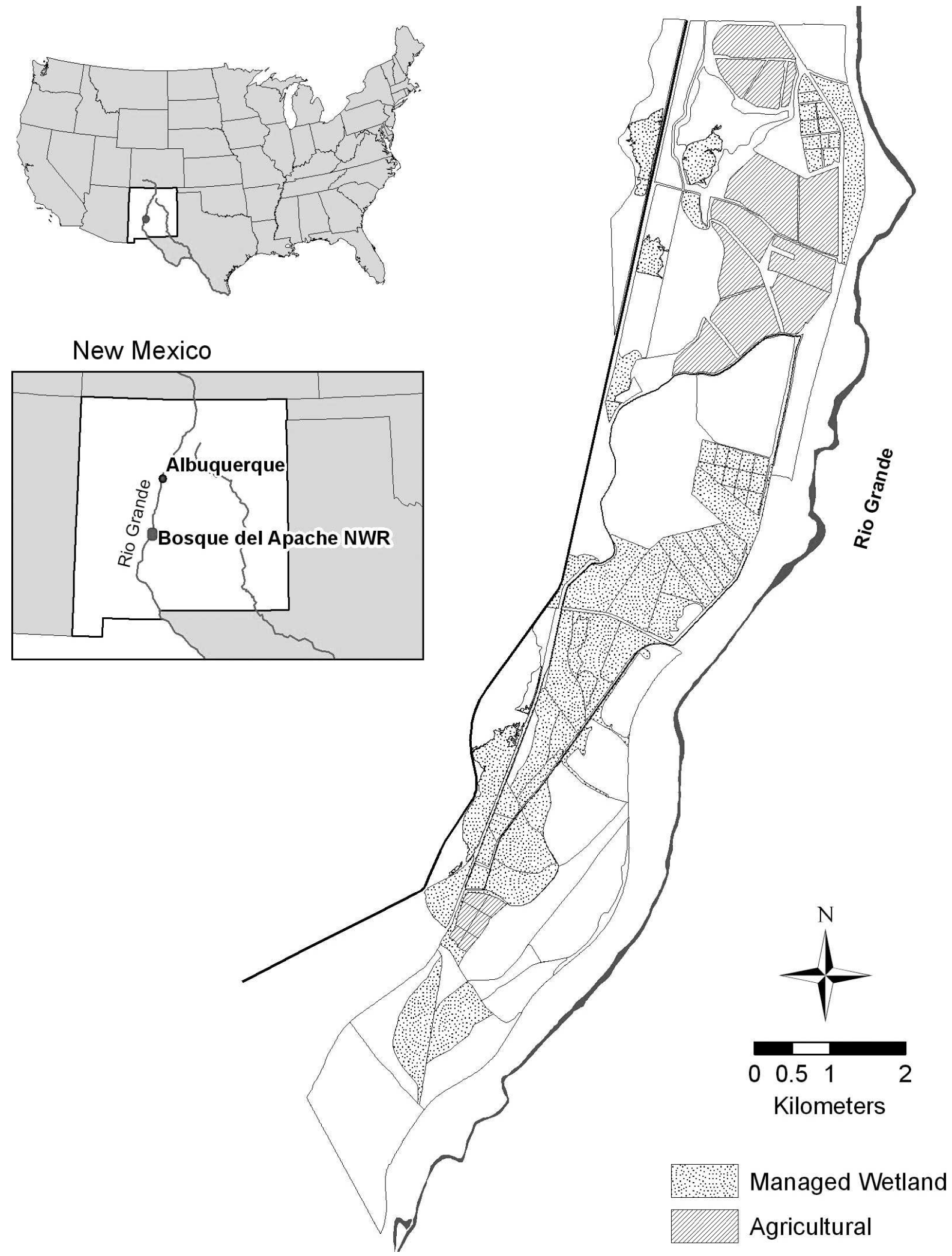

Figure 2. Location and map illustrating complexity of major hydrologic units at Bosque del Apache National Wildlife Refuge, NM (by C. Lee, U.S. Fish and Wildlife Service). 
Mullins 1985, McDaniel and Taylor 2003). In the early 1990s, refuge staff began looking at historical river hydrographs relative to seed rain (deposition) of native woody species. Studies in riparian systems throughout the west had demonstrated that native species such as cottonwood and willow released their seed in late spring, consistent with historic overbank flooding events (Johnson 1965). The seeds, unlike species in seasonal wetlands, do not persist in a seed bank and only survive a few weeks. Restricting overbank flooding after snow melt or removing the water for human use essentially eliminates future regeneration of cottonwood/willow riparian habitats. Salt cedar, on the other hand, produces seeds throughout the growing season and although the seeds also fail to persist in the seed bank, they can germinate any time seasonal moisture provides a moist seed bed (Frasier and Johnsen 1991).

Simulating overbank flooding events or coordinating with water managers to create overbank flooding offered the potential of restoration. Bosque del Apache NWR cleared small plots of salt cedar adjacent to the river, and in two subsequent years, 1993 and 1994, the U.S. Army Corps of Engineers released water from Cochiti Dam, allowing overbank flooding during peak seed release by willow and cottonwood (Taylor et. al. 1999). Obviously, this required a great deal of cooperation among agencies, which was facilitated by earlier cooperation and discussions among personnel. Cottonwood, willow, and salt cedar germinated in cleared plots, with salt cedar achieving the highest densities. However, with simultaneous germination, cottonwood and willow were competitively superior to salt cedar (Sprenger et al. 2002, Bhattacharjee et al. 2006). Over a decade later, cottonwood is dominant in those original plots, testifying to a very successful restoration (Taylor et al. 2006). Overbank flooding in late spring was then simulated on managed units of the refuge following salt cedar removal. Using newly constructed berms and water-delivery structures, water was ponded in units and drawn down during seed rain. Extensive restoration of native riparian woody habitat occurred. Areas were restored in different years, creating a mosaic of different aged riparian habitats (Dello Russo and Vradenburg, U.S. Fish and Wildlife Service, pers. comm.).

Concurrent with these efforts, refuge staff were discussing the potential of converting a portion of the refuge's agricultural fields to seasonal wetlands, typically referred to as moist-soil wetlands (Fredrickson and Taylor 1982). Moist-soil wetlands are dominated by annual seed-producing plants that provide a food source for a diversity of migratory birds. Using the water delivery system in existence and the refuge's water right as a source of irrigation water, seasonal hydroperiods were mimicked by soaking soils in the spring and occasionally in summer; annual grasses and forbs responded positively. Scientific advice and applied research refined techniques for establishing seasonal wetlands (Taylor and Smith 2003). Building on this success, other portions of the managed refuge were converted from salt cedar monocultures or salt flat scrub to seasonal wetlands. In these areas, salt cedar was first controlled and new water conveyance structures were installed to allow emulation of proper hydroperiods. The areas managed for seasonal wetlands varied on an annual basis to simulate natural climate patterns, allowing the wetlands to undergo natural aerobic processes.

Finally, efforts were initiated to re-establish wet meadows typically dominated by salt grass (Distichlis spicata L. Greene). Historically, this wetland type was maintained by high water tables (subirrigated) but seldom experienced prolonged surface water during the growing season or water depths more than a few centimeters. The water table throughout most of the historic floodplain has been lowered due to water conveyance ditches networked through the refuge, which can often capture and transport groundwater. The refuge has documented that if water can be held in controlled areas (impoundments or ditches) adjacent to remnant meadows, local water tables can be manipulated for the benefit of more salt-tolerant grass species (Dello Russo and Vradenburg, pers. comm.). This process sub-irrigates the meadows and is allowing expansion of this sensitive community.

In total, these conservation techniques mimic natural hydrologic processes, which in turn permit proper wetland processes to occur and restore suitable wetland habitats in this drastically modified landscape. This restoration supports viable habitats for a diverse native biota and a variety of other ecosystem services, all of which were set up with partnerships seeking wetland science advice and attaining non-traditional fiscal support.

\section{CONCLUSIONS}

Wetland managers are frequently faced with systems where the original, natural processes that maintained ecosystem productivity and services have been greatly altered. We note that managers who can determine the hydrogeomorphic setting and temporal cycles of the specific wetlands they manage and incorporate that knowledge into management 
plans stand the best chance of implementing successful prescriptions to restore original wetland services, such as wildlife habitat. This is because the examination allows development of prescriptions that restore or simulate natural processes within disturbed systems to achieve the desired services and achieve ecosystem sustainability. Of course, this success must also have sufficient administrative and policy support. Justifying the need for this support, to administrators and politicians on the sound foundation of restoration of natural processes for a return of sustainable ecosystem services for the overall benefit of society, is often prudent. Moreover, we note that developing partnerships among governmental and non-governmental agencies often opens up additional forms of funding for these restoration ventures.

\section{ACKNOWLEDGMENTS}

We appreciate the comments and suggestions by Gina Dello Russo, David Mushet, John Vradenburg, David Haukos, and Darold Batzer. Colin Lee constructed the figure of Bosque del Apache NWR and Judy Sexton coordinated editorial revision. Partial support for preparation of this manuscript was provided by Oklahoma State University and the Environmental Protection Agency Region 6. This article is contribution \#1479 of the USGS Great Lakes Science Center.

\section{LITERATURE CITED}

Albert, D. A., D. A. Wilcox, J. W. Ingram, and T. A. Thompson. 2005. Hydrogeomorphic classification for Great Lakes coastal wetlands. Journal of Great Lakes Research 31, Supplement $1: 129-46$.

Anderson, S. H. 1982. Effects of the 1976 Seney National Wildlife Refuge wildfire on wildlife and wildlife habitat. U.S. Fish and Wildlife Service Resource Publication 146.

Auble, G. T., J. M. Friedman, and M. L. Scott. 1994. Relating riparian vegetation to present and future streamflows. Ecological Applications 4:544-54.

Bhattacharjee, J., J. P. Taylor, Jr., and L. M. Smith. 2006. Controlled flooding and staged drawdown for restoration of native cottonwoods in the Middle Rio Grande Valley, New Mexico. Wetlands 26:691-702.

Brinson, M. M. 1990. Riverine forests. p. 87-141. In A. E. Lugo, M. M. Brinson, and S. Brown (eds.) Forested Wetlands, Volume 15 of Ecosystems of the World Series. Elsevier Scientific Publishers, Amsterdam, The Netherlands.

Brinson, M. M. 1993. A hydrogeomorphic classification for wetlands. U.S. Army Corps of Engineers, Washington, DC, USA.Technical Report WRP-DE-4.

Brinson, M. M., R. R. Christian, and L. K. Blum. 1995. Multiple states in the sea-level induced transition from terrestrial forest to estuary. Estuaries 18:648-59.

Brinson, M. M. and J. Verhoeven. 1999. Chapter 8. Riparian Forests. p. 265-99. In M. L. Hunter (ed.) Maintaining Biodiversity in Forested Ecosystems. Cambridge University Press, Cambridge, UK.
Brown, K. J. and G. B. Pasternack. 2004. The geomorphic dynamics and environmental history of an upper deltaic floodplain tract in the Sacramento-San Joaquin Delta, California, USA. Earth Surface Processes and Landforms 29:1235-58.

Christian, R. R., L. E. Stasavich, C. R. Thomas, and M. M. Brinson. 2000. Reference is a moving target in sea-level controlled wetlands. p. 805-925. In M. P. Weinstein and D. A. Kreeger (eds.) Concepts and Controversies in Tidal Marsh Ecology. Kluwer Academic Publishers, Dordrecht, The Netherlands.

Cooper, D. J., L. H. MacDonald, S. K. Wenger, and S. W. Woods. 1998. Hydrologic restoration of a fen in Rocky Mountain National Park, Colorado, USA. Wetlands $18: 335-45$.

Cowardin, L. M., V. Carter, F. C. Golet, and E. T. LaRoe. 1979. Classification of wetlands and deepwater habitats of the United States. U.S. Fish and Wildlife Service, Washington, DC, USA.Biological Services Project FWS/OBS - 79/31.

Dahl, A. L., D. H. Johnson, L. D. Igl, K. L. Baer, M. A. Johnson, and R. E. Reynolds. 2003. American avocet nesting on constructed islands in North Dakota. Prairie Naturalist 35:95-105.

Dahl, T. E. 1990. Wetlands losses in the United States, 1780's to 1980 's. U. S. Department of the Interior, Fish and Wildlife Service, Washington, DC, USA.

Davis, C. B., A. Campbell, M. Hoosein, P. Kudlu, J. Morgan, C. Pirkle, and B. Welch. 2006. Wetland renovation in East Harbor State Park, Lakeside/Marblehead, Ohio. Lake Erie Commission, Toledo, OH, USA. Final Report LEPF 99-03.

Day, J., G. Shaffer, L. Britsch, D. Reed, S. Hawes, and D. Cahoon. 2000. Pattern and processes of land loss in the Mississippi delta: a spatial and temporal analysis of wetland habitat change. Estuaries 23:425-38.

Dendy, F. E. 1968. Sedimentation in the Nation's reservoirs. Journal of Soil and Water Conservation 23:135-37.

Dugan, P. 1993. Wetlands in Danger. Michael Beasley, Reed International Books, London, UK.

Environment Canada, (D. A. Wilcox, N. Patterson, T. A. Thompson, D. Albert, R. Weeber, J. McCracken, T. Whillans, and J. Gannon, contributors). 2002. Where Land Meets Water: Understanding Wetlands of the Great Lakes. Environment Canada, Toronto, Ontario, Canada.

Euliss, N. H. Jr., R. A. Gleason, A. Olness, R. L. McDougal, H. R. Murkin, R. D. Robarts, R. A. Bourbonniere, and B. G. Warner. 2006. North American prairie wetlands are important non-forested land-based carbon storage sites. Science of the Total Environment 361:179-88.

Euliss, N. H. Jr., R. L. Jarvis, and D. S. Gilmer. 1989. Carbonate deposition on tail feathers of ruddy ducks using evaporation ponds. Condor 91:803-06.

Euliss, N. H. Jr., J. W. LaBaugh, L. H. Fredrickson, D. M. Mushet, G. A. Swanson, T. C. Winter, D. O. Rosenberry, and R. D. Nelson. 2004. The wetland continuum: a conceptual framework for interpreting biological studies. Wetlands $24: 448-58$

Euliss, N. H. Jr. and D. M. Mushet. 2004. Impacts of water development on aquatic macroinvertebrates, amphibians, and plants in wetlands of a semi-arid landscape. Aquatic Ecosystem Health and Management 1:73-84.

Euliss, N. H. Jr., L. M. Smith, D. A. Wilcox, and B. A. Browne. 2008. Linking ecological processes with wetland management goals: charting a course for a sustainable future. Wetlands 28:553-62.

Frasier, G. W. and T. N. Johnsen, Jr. 1991. Saltcedar (Tamarisk): classification, distribution, ecology, and control. p. 377-86. In L. F. James, J. O. Evans, M. H. Ralphs, and R. D. Childs (eds.) Noxious Range Weeds. Westview Press, Boulder, CO, USA.

Fredrickson, L. H. and T. S. Taylor. 1982. Management of seasonally flooded impoundments for wildlife. U.S. Fish and Wildlife Service Resource Publication 148. 
French, J. R. P., D. A. Wilcox, and S. J. Nichols. 1999. Passing of northern pike and common carp through experimental barriers designed for use in wetland restoration. Wetlands 19:883-88.

Friedman, J. M., W. R. Osterkamp, M. L. Scott, and G. T. Auble. 1998. Downstream effects of dams: regional patterns in the Great Plains. Wetlands 18:619-33.

Gagliano, S. M., K. J. Meyerarendt, and K. M. Wicker. 1981. Land loss in Mississippi River deltaic plain. AAPG BulletinAmerican Association of Petroleum Geologists 65:1684-85.

Gilmer, D. S., M. R. Miller, R. D. Bauer, and J. R. LeDonne. 1982. California's Central Valley wintering waterfowl: concerns and challenges. Transactions of the North American Wildlife and Natural Resources Conference 47:441-52.

Gleason, R. A., N. H. Euliss, Jr., D. E. Hubbard, and W. G. Duffy. 2003. Effects of sediment load on emergence of aquatic invertebrates and plants from wetland soil egg and seed banks. Wetlands 23:26-34.

Gottgens, J. F., B. P. Schwartz, R. W. Kroll, and M. Eboch. 1998. Long-term GIS-based records of habitat changes in a Lake Erie coastal marsh. Wetland Ecology and Management 6:5-17.

Groffman, P. M., D. J. Bain, L. E. Band, K. T. Belt, G. S. Brush, J. M. Grove, R. V. Pouyat, I. C. Yesilonis, and W. C. Zipperer. 2003. Down by the riverside: urban riparian ecology. Frontiers in Ecology and the Environment 1:315-21.

Haukos, D. A. and L. M. Smith. 2003. Past and future impacts of wetland regulations on playa ecology in the Southern Great Plains. Wetlands 23:577-89.

Hopkinson, C. S. 1985. Shallow water benthic and pelagic metabolism: evidence for heterotrophy in the nearshore. Marine Biology 87:19-32.

Johnson, D. L., E. C. Braig IV, and W. L. Lynch, Jr. 2004. The fish assemblage of Metzger Marsh after restoration; a final report to the U.S. Geological Survey. Ohio State University, Columbus, OH, USA. Agreement Number 99HQ5A0485.

Johnson, D. L., W. E. Lynch, Jr., and T. W. Morrison. 1997. Fish communities in a diked Lake Erie wetland and an adjacent undiked area. Wetlands 17:43-54.

Johnson, R. L. 1965. Revegetating cottonwood from natural seedfall. Journal of Forestry 63:33-36.

Johnson, W. C., R. L. Burgess, and W. R. Keammerer. 1976. Forest overstory vegetation on the Missouri River floodplain in North Dakota. Ecological Monographs 46:59-84.

Junk, W. J., P. B. Bayley, and R. E. Sparks. 1989. The flood-pulse concept in river floodplain systems. p. 110-27. In D. P. Dodge (ed.) Proceedings of the International Large River Symposium, Canadian Special Publication of Fisheries and Aquatic Sciences 106.

Junk, W. J. and K. M. Wantzen. 2006. Flood pulsing and the development and maintenance of biodiversity in floodplains. p. 407-35. In D. P. Batzer and R. R. Sharitz (eds.) Ecology of Freshwater and Estuarine Wetlands. University of California Press, Berkeley, CA, USA.

Kaatz, M. R. 1955. The Black Swamp: a study in historical geography. Annals of the Association of American Geographers 45:1-35.

Kearney, M. S. and J. C. Stevenson. 1991. Island land loss and marsh vertical accretion rate evidence for historical sea-level changes in Chesapeake Bay. Journal of Coastal Research 7:403-15.

Keddy, P. A. and A. A. Reznicek. 1986. Great Lakes vegetation dynamics: the role of fluctuating water levels and buried seeds. Journal of Great Lakes Research 12:25-36.

King, S. L. and J. A. Allen. 1996. Plant succession and greentree reservoir management: implications for management and restoration of bottomland hardwood wetlands. Wetlands 16:503-11.

Kneib, R. T. and S. L. Wagner. 1994. Nekton use of vegetated marsh habitats at different stages of tidal inundation. Marine Ecology-Progress Series 106:227-38.

Knighton, D. 1998. Fluvial Forms and Processes. John Wiley \& Sons, Inc., New York, NY, USA.
Kowalski, K. P. and D. A. Wilcox. 1999. Use of historical and geospatial data to guide the restoration of a Lake Erie coastal marsh. Wetlands 19:858-68.

Kowalski, K. P. and D. A. Wilcox. 2003. Differences in sedge fen vegetation upstream and downstream from a managed impoundment. American Midland Naturalist 150:199-220.

Kroes, D. and M. M. Brinson. 2004. Occurrence of riverine wetlands on floodplains along a climatic gradient. Wetlands 24:167-77.

Leopold, L. B., M. G. Wolman, and J. P. Miller. 1964. Fluvial Processes in Geomorphology. Freeman, San Francisco, CA, USA.

Linsley, R. K., J. B. Franzini, D. L. Freyberg, and G. Tchobanoglous. 1992. Water Resources Engineering, fourth edition. McGraw-Hill, New York, NY, USA.

Lokemoen, J. T. 1973. Waterfowl production on stock-watering ponds in the northern plains. Journal of Range Management 26:179-84.

Lotze, H. K., H. S. Lenihan, B. J. Bourque, R. H. Bradbury, R. G. Cooke, M. C. Kay, S. M. Kidwell, M. X. Kirby, C. H. Peterson, and J. B. C. Jackson. 2006. Depletion, degradation, and recovery potential of estuaries and coastal seas. Science 312:1806-09.

Luo, H. R., L. M. Smith, B. L. Allen, and D. A. Haukos. 1997. Effects of sedimentation on playa wetland volume. Ecological Applications 7:247-52.

Luo, H. R., L. M. Smith, D. A. Haukos, and B. L. Allen. 1999. Sources of recently deposited sediments in playa wetlands. Wetlands 19:176-81.

Markham, C. A., W. E. Lynch, Jr., D. L. Johnson, and R. W. Petering. 1997. Comparison of white perch populations in diked and undiked Lake Erie wetlands. Ohio Journal of Science 97:72-77.

McDaniel, K. C. and J. P. Taylor. 2003. Saltcedar recovery after herbicide-burn and mechanical clearing practices. Journal of Range Management 56:439-45.

Megonigal, J. P., W. H. Conner, S. Kroeger, and R. R. Sharitz. 1997. Aboveground production in Southeastern floodplain forests: a test of the subsidy-stress hypothesis. Ecology 78:370-84.

Mensik, J. G. and F. L. Paveglio. 2004. Biological integrity, diversity, and environmental health policy and the attainment of refuge purposes: a Sacramento National Wildlife Refuge case study. Natural Resources Journal 44:1161-83.

Merbach, W., T. Kalettka, C. Rudat, and J. Augustin. 2002. Trace gas emissions from riparian areas of small eutrophic inland waters in Northeast-Germany. p. 235-44. In G. Broll, W. Merbach, and E. V. Pfeiffer (eds.) Wetlands in Central Europe-Soil Organisms, Soil Ecological Processes, and Trace Gas Emissions. Springer, Berlin, Heidelberg, Germany.

Mitsch, W. J. and J. G. Gosselink. 2007. Wetlands, fourth edition. John Wiley \& Sons, Inc., New York, NY, USA.

National Research Council. 1995. Wetlands-Characteristics and Boundaries. National Academy Press, Washington, DC, USA.

National Research Council. 2002. Riparian Areas: Functions and Strategies for Management. National Academy Press, Washington, DC, USA.

Nichols, S. J. and D. A. Wilcox. 1997. Burrowing saves Lake Erie clams. Nature 389:921.

Nichols, S. J. and D. A. Wilcox. 2002. Reestablishing the freshwater unionid population of Metzger Marsh, Lake Erie. Report to U.S. Environmental Protection Agency-Great Lakes National Program Office. Chicago, IL, USA.IAG No. 14947830-01.

Nichols, S. J. and D. A. Wilcox. 2004. Native clams find refuge from zebra mussels in Metzger Marsh, a lake-connected wetland in western Lake Erie. Ecological Restoration 22:51-52.

Odum, E. P. 1980. The status of three ecosystem level hypotheses regarding salt marshes: tidal subsidy, outwelling and the detritus based food chain. p. 485-96. In V. S. Kennedy (ed.) Estuarine Perspectives. Academic Press, New York, NY, USA. 
Odum, W. E. 1988. Comparative ecology of tidal fresh-water and salt marshes. Annual Review of Ecology and Systematics 19:147-76.

Ohlendorf, H. M., D. J. Hoffman, M. K. Saiki, and T. W. Aldrich. 1986a. Embryonic mortality and abnormalities of aquatic birds: apparent impacts by selenium from irrigation drainwater. Science of the Total Environment 52:49-63.

Ohlendorf, H. M., R. L. Hothem, C. M. Bunck, T. W. Aldrich, and J. F. Moore. 1986b. Relationships between selenium concentrations and avian reproduction. Transactions of the North American Wildlife and Natural Resources Conference $51: 330-42$.

Okruszko, H. 1995. Influence of hydrological differentiation of fens on their transformation after dehydration and on the possibilities for restoration. p. 113-19. In B. D. Wheeler, S. C. Shaw, W. J. Fojt, and R. A. Robertson (eds.) Restoration of Temperate Wetlands. John Wiley \& Sons Ltd., Chichester, UK.

Paul, M. J. and J. L. Meyer. 2001. Streams in the urban landscape. Annual Review of Ecology and Systematics $32: 333-65$.

Presser, T. S. and I. Barnes. 1985. Dissolved constituents including selenium in waters in the vicinity of Kesterson National Wildlife Refuge and West Grasslands, Fresno and Merced Counties, California. U. S. Geological Survey Water Resources Investigations Report 85-4220.

Richardson, C. J. 1985. Mechanisms controlling phosphorus retention capacity in freshwater wetlands. Science 228: 1424-27.

Robb, D. and W. J. Mitsch. 1989. Hydroperiods and water chemistry in diked and undiked wetlands in western Lake Erie. p. 113-34. In W. J. Mitsch (ed.) Wetlands of Ohio's Coastal Lake Erie: a Hierarchy of Systems. Ohio State University, Columbus, OH, USA.

Rosgen, D. 1995. Applied River Morphology. Wildland Hydrology, Pagosa Springs, CO, USA.

Shaffer, T. L., A. L. Dahl, R. E. Reynolds, K. L. Baer, M. A. Johnson, and G. A. Sargeant. 2006. Determinants of mallard and gadwall nesting on constructed islands in North Dakota. Journal of Wildlife Management 70:129-37.

Silvester, R. and J. R. C. Hsu. 1991. New and old ideas in coastal sedimentation. Reviews in Aquatic Sciences 4:375-410.

Smith, L. M. 1990. Waterfowl habitat management and research in North America. International Union of Game Biologists 19:468-76.

Smith, L. M. 2003. Playas of the Great Plains. University of Texas Press, Austin, TX, USA.

Smith, L. M. and D. A. Haukos. 2002. Floral diversity in relation to playa wetland area and watershed disturbance. Conservation Biology 16:964-74.

Sprenger, M. D., L. M. Smith, and J. P. Taylor. 2002. Restoration of riparian habitat using experimental flooding. Wetlands 22:49-57.
Sweet, W. V. and J. W. Geratz. 2003. Bankfull hydraulic geometry relationships and recurrence intervals for North Carolina's coastal plain. Journal of the American Water Resources Association 39:861-71.

Swenson, E. A. and C. L. Mullins. 1985. Revegetating riparian trees in southwestern floodplains. p. 135-38. In R. R. Johnson, C. D. Ziebell, D. R. Patton, P. F. Ffolliott, and R. H. Hamre (eds.) Riparian Ecosystems and their Management: Reconciling Conflicting Uses. U.S. Forest Service General Technical Report RM-120.

Taylor, J. T. and L. M. Smith. 2003. Chufa management in the Middle Rio Grande Valley, New Mexico. Wildlife Society Bulletin 31:156-62.

Taylor, J. T., L. M. Smith, and D. A. Haukos. 2006. Evaluation of woody plant restoration in the Middle Rio Grande: 10 years after. Wetlands 26:1150-59.

Taylor, J. T., D. B. Wester, and L. M. Smith. 1999. Soil disturbance, flood management, and riparian woody plant establishment in the Rio Grande floodplain. Wetlands 19:372-82.

U.S. Environmental Protection Agency. 2000. National water quality inventory: 2000 report to Congress. U.S. Environmental Protection Agency, Washington, DC, USA. EPA841-R-02-001.

Walter, R. C. and D. J. Merritts. 2008. Natural streams and the legacy of water-powered mills. Science 319:299-304.

Warren, R. S., P. E. Fell, R. Rozsa, A. H. Brawley, A. C. Orsted, V. Swamy, and W. A. Niering. 2002. Salt marsh restoration in Connecticut: 20 years of science and management. Restoration Ecology 10:497-513.

Wilcox, D. A. 1995. The role of wetlands as nearshore habitat in Lake Huron. p. 223-45. In M. Munawar, T. Edsall, and J. Leach (eds.) The Lake Huron Ecosystem: Ecology, Fisheries and Management. Ecovision World Monograph Series. S.P.B. Academic Publishing, Amsterdam, The Netherlands.

Wilcox, D. A. and S. J. Nichols. 2008. The effect of water-level fluctuations on plant zonation in a Saginaw Bay, Lake Huron wetland. Wetlands 28:487-501.

Wilcox, D. A., M. J. Sweat, M. L. Carlson, and K. P. Kowalski. 2006. A water-budget approach to restoring a sedge fen affected by diking and ditching. Journal of Hydrology 320:501-17.

Wilcox, D. A. and T. H. Whillans. 1999. Techniques for restoration of disturbed coastal wetlands of the Great Lakes. Wetlands 19:835-57.

Williams, P. B. and M. K. Orr. 2002. Physical evolution of restored breached levee salt marshes in the San Francisco Bay Estuary. Restoration Ecology 10:527-42.

Wolanski, E. 2007. Estuarine Ecohydrology. Elsevier, Amsterdam, The Netherlands.

Zartman, R. E., R. H. Ramsey, P. W. Evans, G. Koenig, C. Truky, and L. Kamara. 1996. Outerbasin, annulus, and playa basin infiltration studies. Texas Journal of Agriculture and Natural Resources 9:23-32.

Manuscript received 20 August 2007; accepted 10 April 2008. 